\title{
Densities, Viscosities and Refractive Indices of n- Butanol + Allyl Chloride Mixture at 298K
}

\author{
Aruna P. Maharolkar, Y. Sudke, S. Kamble \& A Tidar \\ Microwave Research Lab, Department of Physics \\ Dr Babasaheb Ambedkar Marathwada University \\ Aurangabad-431004 MS, INDIA \\ Tel: 91-932-622-2790_E-mail: aruna_physics@rediffmail.com \\ A. G. Murugkar, S.S. Patil \& P. W. Khirade (Corresponding author) \\ Department of Physics, Dr. Babasaheb Ambedkar Marathwada University \\ Aurangabad-431004 MS, INDIA \\ E-mail: pwk004@yahoo.com \\ S. C. Mehrotra \\ Department of Computer Science \& Information Technology \\ Dr. Babasaheb Ambedkar Marathwada University \\ Aurangabad-431004, INDIA
}

\begin{abstract}
The density $\rho$, viscosity $\eta$, refractive index $n$ and dielectric constant $\varepsilon_{\mathrm{s}}$ of binary mixture of Allyl Chloride (AC) with n-Butanol including those of the pure liquids, were measured over the complete composition range at $298 \mathrm{~K}$. The experimental data is used to calculate excess molar volumes $\left(\mathrm{v}^{\mathrm{E}}\right)$, excess permittivity $\left(\varepsilon_{\mathrm{s}}^{\mathrm{E}}\right)$, excess viscosity $\left(\eta^{\mathrm{E}}\right)$, excess refractive index, molar refraction, excess molar polarization and Dunstan's constant. The variations of these parameters with composition and the effect of bonding in the binary mixture are discussed from the point of view of intermolecular interactions in these mixtures. The positive value of excess molar volume $\left(\mathrm{v}^{\mathrm{E}}\right)$ is attributed to the breaking of $\mathrm{H}$-bonded associated species formed between unlike molecule at $298 \mathrm{~K}$.
\end{abstract}

Keywords: Excess density, Intermolecular interactions, Excess viscosity

\section{Introduction}

The particular manner whereby solute and solvent molecules are associated with one another in a liquid mixture brings about a distinct effect on the properties of the resulting system. Although physical properties of pure liquids abound in the literature, such properties measured for binary systems have been rather scarcely investigated up to now. Previously we described the intermolecular interactions between the components of Alcohols with other groups of liquids. In this work we extend the study by investigating properties like density, refractive index \& viscosity. Ordinary liquids are made up of large molecules bound by weakly directional van der Waals forces; n-Butanol on the contrary, is made up of small molecules strongly bound by hydrogen bonds, in order of magnitude greater than van der Waals forces.

Hydrogen bonds in butanol are responsible for the striking behavior, and in some instances provide evidence for the role of butanol in the sequence of chemical reactions. Hydrogen bonding in butanol is believed to be highly cooperative, i.e., interaction of butanol molecule with a cluster of hydrogen bonded molecules is more likely than interaction with a single molecule to give a dimmer. Binary \& ternary representations and prediction of intermolecular interactions with liquid dynamics by using reliable models intermolecular interactions is an essential task of considerable importance to gain some insights into the interactions among the groups of molecules or in important technological applications such as mass transfer, fluid flow heat transfer, design calculation or separation processes. To predict nature of interactions within the binary system excess properties were used. 
In $\mathrm{AC}(\mathrm{CH} 2=\mathrm{CHCH} 2 \mathrm{Cl})$ molecules strong dipole - dipole interaction exists. Strong hydrogen bonding is present in n-Butanol $\left(\mathrm{C}_{4} \mathrm{H}_{9} \mathrm{OH}\right)$ molecules. Because of presence of different type of association in both molecules, it is interesting to study the nature of intermolecular interactions between n-Butanol + Allyl Chloride. Allyl chloride is a common alkylating agent, useful in the manufacture of pharmaceuticals and pesticides. n-Butanol is used in the manufacture of pharmaceuticals. n-Butanol is also used as an extractant in the manufacture of antibiotics, hormones, and vitamins (Mellan, I., 1950; Doolittle, 1954); industrial uses of n-Butanol are as polymers, pyroxylin plastics, herbicide esters; n-Butanol is used as an ingredient in perfumes and as solvents for the extraction of essential oils (Doolittle, 1954), a solvent for paints, coatings, natural resins, gums, synthetic resins, dyes, alkaloids, and camphor. Alcohols play an important role in many chemical reactions due to its ability to undergo self-association with manifold internal structures and are in wide use in industries and science as reagents, solvents and fuels (Jui, 2005).

\section{Experimental}

\subsection{Chemicals}

The chemicals used in the present paper (n-Butanol \& AC) are of spectroscopic grade and were used without further purification. The solutions were prepared at eleven different volume percentage of $\mathrm{AC} 0 \%$ to $100 \%$ in steps of $10 \%$ within $0.02 \%$ error limit.

\subsection{Measurements}

Viscosities were measured using Brookfield Viscometer with an accuracy of $\pm 1 \%$ for small sample size of $1 \mathrm{ml}$. Refractive indices (at Sodium D line) were measured by using Abbe Refractometer thermostated with constant water bath with precision of \pm 0.001 and the values presented here are the mean values from five independent readings for each sample.

Density is measured using specific gravity bottle having an internal volume $3 \mathrm{ml}$ and was calibrated with distilled water at $298 \mathrm{~K}$. Three specific gravity bottles were immersed in a thermostatic bath which was controlled at $298 \mathrm{~K}$. A precision digital thermometer with a thermister probe was used to read the temperature with an accuracy of $\pm 0.10 \mathrm{~K}$. The mixture densities were obtained by averaging the results from these three specific gravity bottles.

Dielectric constant is measured by using self developed setup in our laboratory.

\section{Result \& Discussion}

The measured and estimated values of refractive index, density, viscosity and dielectric constant at $298 \mathrm{~K}$ are given in table 1 . The density of the binary mixture of $\mathrm{AC}$ and n-Butanol is increasing as a mole fraction of $\mathrm{AC}$ in the mixture is increasing. This is expected because density of pure AC is more than that of pure n-Butanol. This variation of density is shown in table 1 . From table 1 it can also be seen that the refractive index (n) is increasing with increase in mole fraction of $\mathrm{AC}$ in the mixture. This increase in $\mathrm{n}$ is further supported by the increase in density of the mixture with increase in mole fraction of AC.

Viscosity decreases as the mole fraction of AC in the binary mixture increases, as shown in table 1. Decrease in viscosity of the binary mixture can be attributed to decrease in the effect of hydrogen bonding with increase in mole fraction of allyl chloride. This is because n-Butanol is more viscous than AC. It is due to presence of strong hydrogen bonding in n-Butanol and more number of carbon atom and long straight chain compound. Figure 1 shows that the excess viscosity is positive.

The values of dielectric constant decrease with increase in mole fraction of AC in the mixture, as can be seen from the fifth column of table 1 . This can be attributed to the decrease in hydrogen bonding in the mixture. This is because there is dipole - dipole interaction in pure $\mathrm{AC}$ and strong hydrogen bonding as in pure n-Butanol.

From figure 2 and 3, we see that the excess refractive index and excess density are negative, indicating the existence of intermolecular interaction and that these two excess parameters are supporting each other.

The Excess molar volumes $v_{m}^{E}$ were calculated by using the following relation (El Hefnawy M, 2005; Yaw,

$$
v_{\mathrm{m}}^{\mathrm{E}}=\mathrm{x}_{1} \mathrm{M}_{1}\left(\frac{1}{\rho}-\frac{1}{\rho_{1}}\right)+\mathrm{x}_{2} \mathrm{M}_{2}\left(\frac{1}{\rho}-\frac{1}{\rho_{2}}\right)
$$


where $\mathrm{M}$ is the molecular mass; subscripts 1 and 2 stand for the pure components, $\mathrm{AC}$ and $\mathrm{n}$-Butanol respectively.

The variation of $v_{m}$ as mole fraction of $\mathrm{AC}$ is shown in figure 4. In pure n-Butanol, molecules are hydrogen bonded. On adding AC, these molecules get in between the n-Butanol molecules breaking the hydrogen bonds of $\mathrm{n}$-Butanol molecules, thus leading to multimer formation. This changes the intermolecular interaction pattern and becomes the cause for decrease in molar volume of the mixture with increase in mole fraction of AC in the mixture as shown in figure 4 . The excess molar volume is positive, as shown in figure 5 . This fact is further supported by the negative excess density, shown in figure 3 .

Excess permittivity is given by $(25-26)$

$$
\varepsilon_{\mathrm{s}}^{\mathrm{E}}=\left(\varepsilon_{\mathrm{s}}\right)_{\mathrm{m}}-\left[\left(\varepsilon_{\mathrm{s}}\right)_{\mathrm{A}} \mathrm{x}_{\mathrm{A}}+\left(\varepsilon_{\mathrm{s}}\right)_{\mathrm{B}} \mathrm{x}_{\mathrm{B}}\right]
$$

The variation of $\varepsilon_{\mathrm{s}}{ }^{\mathrm{E}}$ for increase in mole fraction of $\mathrm{AC}$ in the binary mixture is shown in figure 6 . The positive values of $\varepsilon_{\mathrm{s}}^{\mathrm{E}}$ indicate that the solute and solvent interact in such a way that the effective dipole moment increases. There is formation of monomers and dimers.

Molar refraction is given by the formula

$$
\mathrm{R}=\mathrm{v}_{\mathrm{m}}\left[\left(\mathrm{n}^{2}-1\right) /\left(\mathrm{n}^{2}+2\right)\right]
$$

Figure 7 shows that the molar refraction decreases with increase in mole fraction of $\mathrm{AC}$ in the mixture. As molar refraction is a measure of total polarizability of a mole of a substance and is dependent on index of refraction and temperature, decrease in molar refraction indicates the decrease in molar polarization and decrease in dielectric constant with increase in the mole fraction of AC increases in the mixture.

Molar polarization is given by

$$
\mathrm{P}_{\mathrm{m}}=[(\varepsilon-1) /(\varepsilon+2)] .(\mathrm{M} / \rho)
$$

The estimated $\mathrm{P}_{\mathrm{m}}$ is shown in figure 8. Decrease in $\mathrm{P}_{\mathrm{m}}$ with increase in mole fraction of AC in the mixture also indicates the decrease in the effect of hydrogen bonding in the mixture. Figure 9 shows the positive excess molar polarization for different mole fraction of $\mathrm{AC}$ in the mixture.

Dunstan's constant is given by

$$
(\rho / M) \eta \cdot 10^{6}
$$

The calculated values of Dunstan's constant are shown in figure 10.

Dunstan (1909) showed that for 'associated liquids' the value of this constant is much higher. From figure 10, it can be seen that higher values of Dunstan's constant are in the range of 30590 - 3000 indicating the association of the two liquids. The value decreases as the concentration of AC increases. This suggests breaking of hydrogen bonded associated species formed by unlike molecules at same temperature.

The excess properties follow a Redlich -Kister type polynomial equation (23-24)

$$
f\left(x_{1}\right)=x_{1} \cdot\left(1-x_{1}\right) \cdot \sum_{j} B_{j} \cdot\left(1-2 \cdot x_{1}\right)^{j}
$$

This equation is fitted by using method of least squares to all the excess properties. The estimated $B_{j}$ coefficients are given in table 2 . The standard error $(\sigma)$ between the data and the Redlich Kister model for the excess properties is given in the last column of the table. $\sigma$ is calculated by using the relation

$$
\sigma=(\Sigma \text { square of error between data and model/ }(\mathrm{n}-1))
$$

where $\mathrm{n}$ is the number of experimental data points. The graphs of excess properties and the corresponding Redlich-Kister model are shown the figures.

The standard errors in the $B_{j}$ coefficients of the Redlich-Kister model along with the $95 \%$ confidence intervals for all excess properties are given in table 3. Comparison of estimated values refractive index, density, viscosity and dielectric constants for pure liquids (i.e. allyl chloride and n-Butanol) at $298 \mathrm{~K}$ with the literature values is given in table 4 .

\section{Conclusions}

The summary of conclusions of intermolecular interaction between allyl chloride and n-Butanol is as follows: 
- The values of refractive index and density are increasing with increase in mole fraction of allyl chloride. These two parameters are supporting each other.

- Decrease in viscosity of the binary mixture with increase in mole fraction of allyl chloride indicates that effect of hydrogen bonding decreases as mole fraction of allyl chloride increases

- The values of ${ }_{s}$ decrease with the addition of allyl chloride in n-Butanol. This is due to decrease in effect of hydrogen bonding.

- Variations in refractive index, density, viscosity and dielectric constant with mole fraction of AC in the binary mixture of $\mathrm{AC}+\mathrm{n}$-Butanol indicate the existence of intermolecular interaction between $\mathrm{n}$-Butanol and allyl chloride.

- There is monomer and dimer formation in the mixture which is supported by positive excess viscosity, positive excess molar volume, positive excess permittivity, decrease in molar refraction, decrease in molar polarization and decrease in dielectric constant.

- The estimated values of refractive index, density, viscosity for pure liquids at $298 \mathrm{~K}$, are in good agreement with those reported in the literature.

\section{References}

[Online] Available: http://chemicalland21.com/industrialchem/solalc/ALLYL\%20ALCOHOL.htm.

[Online] Available: http://clippercontrols.com/info/dielectric_constants.html.

[Online] Available: http://suppliers.jimtrade.com/3/2913/120934.htm.

[Online] Available: http://www.chemicalland21.com/petrochemical/N-BUTANOL.htm.

[Online] Available: http://www.engineersedge.com/fluid_flow/fluid_data.htm.

[Online] Available: http://www.proximitycontrols.com/servicemanuals/rfandcrf.pdf.

[Online] Available: http://www.sigmaaldrich.com/catalog/ProductDetail.do?N4=A30702\%7CAldrich\&N5=Prod uc t\%20No.\%7CBRAND_KEY\&F=SPEC.

[Online] Available: http://www.solvaychemicals.us/static/wma/pdf/5/0/3/2/CAL.pdf.

A mundsen J., Goodwin R. J. \& Wetzel W. H. (1979). "Water-soluble pentachlorophenol and tetrachlorophenol wood-treating systems", ZA 7801031, published 28 Feb.

Anil Kumar. (2007). Nain Densities and Volumetric Properties of Binary Mixtures of Formamide with 1-Butanol, 2- Butanol, 1,3-Butanediol and 1,4-Butanediol at Temperatures between 293.15 and 318.15 K. J Solution Chem, 36:497-516.

Aurizio Fermeglla and Romano Lapasin. (1988). Excess Volumes and Viscosities of Binary Mixtures of Organics J. Chem. Eng. Data, 33, 415-417

B. E. de Cominges, M. M. Piñeiro, E. Mascato, L. Mosteiro, T. P. Iglesias and J. L. Legido. (2003). RELATIVE PERMITTIVITIES OF BINARY MIXTURES OF 1-BUTANOL + n-ALKANE AT 298.15 K. Journal of Thermal Analysis and Calorimetry, Vol. 72 129.133.

B. E. de Cominges, M. M. Piñeiro, E. Mascato, L. Mosteiro, T. P. Iglesias and J. L. Legido. (2003). RELATIVE PERMITTIVITIES OF BINARY MIXTURES OF 1-BUTANOL + n-ALKANE AT $298.15 \mathrm{~K}$. Journal of Thermal Analysis and Calorimetry, Vol. 72 129. 133.

Bonte, W. (1979). "Congener substances in German and foreign beers", Blutalkohol 16: 108-24, cited in Butanols: four isomers, Environmental Health Criteria monograph No. 65, Geneva: World Health Organization, 1987, ISBN 92-4-154265-9, [Online] Available: http://www.inchem.org/documents/ehc/ehc/ehc65.htm.

C R C Handbook of Chemistry and Physics 64 th Edition 1983-1984 Editor Robert C Weast.

Chan R. K. and Liao S.C. (1970). Canadian Journal of Chemistry, 48, 2988.

Chaudhary A., Mehrotra S. C. (2002). Mol. Phys., 100, 3907.

Dharmalingam K., Ramachandran K., Sivagurunathan, Undre P. B., Khirade P. W., Mehrotra S. C. (2006). Dielectric studies of alkyl acrylates with primary alcohols using time domain reflectometry.Molecular physics, (Taylor \& Francis). 104(18), 2835-2840. 
Doolittle A. K. (1954). The Technology of Solvents and Plasticizers, New York: Wiley, pp.644-45, cited in Butanols: four isomers, Environmental Health Criteria monograph No.65, Geneva: World Health Organization, 1987, ISBN 92-4-154265-9.

Doolittle, A. K. (1954). The Technology of Solvents and Plasticizers, New York: Wiley, pp. 644-45, cited in Butanols: four isomers, Environmental Health Criteria monograph No. 65, Geneva: World Health Organization, 1987, ISBN 92-4-154265-9, [Online] Available: http://www.inchem.org/documents/ehc/ehc/ehc65.htm.

El Hefnawy M and Tanaka R. (2005). Density and Relative Permittivity for 1-Alkanols + Dodecane at 298.15K. J. Cem. Eng. Data, 50, 1651-1656.

Gabriel C., Gabriel S., Grant E. H., Hasted B. S. J. and Mingos D. M. P. (1998). Dielectric parameters relevant to microwave dielectric heating. Chem. Soc. Rev., 27,213.

Garcia, B., Herrera, C., Leal, J.M. (1991). Shear viscosities of binary liquid mixtures: 2-pyrrolidinone with 1-alkanols. J. Chem. Eng. Data, 36, 269-274.

Giner, B. Artigas, H., Carrion, A., Lafuente, C., Royo, F.M. (2003). Excess thermodynamic properties of isomeric butanols with 2-methyl-tetrahydrofuran. J. Mol. Liq., 108, 303-311.

Hall R. L. Oser, B. L. (1965). "Recent progress in the consideration of flavouring ingredients under the food additives amendment. III. Gras substances", Food Technol.: 151, cited in Butanols: four isomers, Environmental Health Criteria monograph No. 65, Geneva: World Health Organization, 1987, ISBN 92-4-154265-9, [Online] Available: http://www.inchem.org/documents/ehc/ehc/ehc65.htm.

J. A. Riddick, W. B. Bunger, and T. K. Sakano. (1986). Organic Solvents, Physical Properties and Methods of Purification (Wiley-Interscience, New York).

J. Peyrelase, C. Boned and J. P. Le Petit. (1981). J. Phys. E. Sci. Instrum., 14, 1002.

Jiminez, E., Cabanas, M., Segade, L., Garcia-Garabal, S. Casas, H. (2001). Excess volumes, changes in refractive index and surface tension of binary 1,2-ethanediol + 1-propanol or 1-butanol mixtures at several temperatures. Fluid Phase Equilib, 180, 151-164.

Jui Tang Chem and Wong Chao Chang. (2005). Densities Viscosities of Binary Mixtures of Propelene Glycol Monomethyl Ether Acetate with Methacrylic Acid, Benzyl Methacrylate and 2-Hydroxyethyl Methacrylate between 298.15K and 318.15K. J Chem. Eng. Data, 50, 1753-1756.

Khirade P.W., Chaudhary A., Shinde J. B., Helambe S. N., Mehrotra S. C. (1999). Static Dielectric Constant and Relaxation Time Measurements on Binary Mixtures of Dimethyl Sulfoxide with Ethanol, 2-Ethoxyethanol, and Propanol at 293, 303, 313, 323K. J. Chem. Engg. Data, 44, 879.

Khirade P.W., Chaudhary A., Shinde J. B., Helambe S. N., Mehrotra S. C. (1999). Temperature dependent Dielectric Relaxation of 2-Ethoxyethanol, Ethanol, and 1-Propanol in Dimethylformamide Solution Using Time Domain Technique. J. Sol. Chem., vol, 28, 1031-1043.

Kuang C. and Nelson S. O. (1997). J. Micro. Pow. And E M Energy, 32,114.

M. Iglesias, B. Orge and J. Tojo. (1996). Fluid Phase Equilibria, 126, 203.

Mellan, I. (1950). Industrial Solvents, New York: Van Nostrand Reinhold, pp. 482-88, cited in Butanols: four isomers, Environmental Health Criteria monograph No. 65, Geneva: World Health Organization, 1987, ISBN 92-4-154265-9, [Online] Available: http://www.inchem.org/documents/ehc/ehc/ehc65.htm.

Mellan, I. (1950). Industrial Solvents, New York: Van Nostrand Reinhold, pp.482-88, cited in Butanols: four isomers, Environmental Health Criteria monograph No. 65, Geneva: World Health Organization, 1987, ISBN 92-4-154265-9, [Online] Available: http://www.inchem.org/documents/ehc/ehc/ehc65.htm.

Monich, J. A. (1968). Alcohols: Their Chemistry, Properties, and Manufacture, New York: Chapman and Reinhold, cited in Butanols: four isomers, Environmental Health Criteria monograph No. 65, Geneva: World Health Organization, 1987, ISBN 92-4-154265-9, [Online] Available: http://www.inchem.org/documents/ehc/ehc/ehc65.htm.

Prabhakar Undre, Helambe S. N., Jagdale S. B., Khirade P. W and Mehrotra S. C. (2007). Microwave dielectric characterization of binary mixture of formamide with N,N-dimethylamionethanol. Pramana, J. of Phy, 68, 5, 851-861. 
R. L. Gardas S.L. (2008). Oswal Volumetric and Transport Properties of Ternary Mixtures Containing 1-Butanol or 1-Pentanol,Triethylamine and Cyclohexane at 303.15 K:Experimental Data, Correlation and Prediction by the ERAS Model J Solution Chem, 37: 1449-1470.

Rana V. A., Vyas A.D. and Mehrotra S. C. (2002). Dielectric relaxation study of mixtures of 1-propanol with aniline, 2-chloroaniline and 3-chloroaniline at different temperatures using time domain reflectometry. $J$. Mol. Liq., 102,379.

Rdlich O. Kister A. T. (1948). Algebraic Representation of thermodynamic properties and classification of solutions. Ind. Eng Chem, 40 345-348

Schreier Peter, Drawert, Friedrich; Winkler, Friedrich. (1979). Composition of neutral volatile constituents in grape brandies. J. Agric. Food Chem., 27 (2): 365-72, doi:10.1021/jf60222a031.

Shannon E. (1949). proc. IRE, 37, 10.

Shirke R. M., Chaudhary A., More N. M., Patil P. B. (2001). J. Mol. Liq., 27,94.

Sivagurunathan P., Dharmalingam K. Ramachandran K., Undre P. B., Khirade P. W., Mehrotra S.C. (2007). Dielectric study of butyl methacrylate-alcohol mixtures by time-domain reflectometry. PHYSICA B, 387-203.

Sivagurunathan P., Dharmalingam K., Ramachandran K., Undre P. B., Khirade P. W. , Mehrotra S. C. (2006). Dielectric relaxation study of mixtures of alkyl methacrylates and 1-alcohols using time domain reflectrometry. Philosophical Magazine letters, (Taylor \& Francis), 86(5), 291-300.

Sivagurunathan P., Dharmalingam K., Ramachandran K., Undre P. B., Khirade P. W., Mehrotra S.C. (2007). Dielectric studies on binary mixtures of ester with alcohol using time domain reflectometry. J. Molecular Liquids, 133-139.

Viscosity of liquids: theory, estimation, experiment, and data0.34 By Dabir S. Viswanath ISBN 10-1-4020-5481-5(HB) Springer Dordeeht. Netherlands.

Yaw Wen Sheu and Chein Hsiun Tu. (2005). Densities Viscosities, Refractive indices and Surface Tensions for 12 flavor Esters from T=288.15K to T=358.15K. J Chem. Eng. Data, 50, 1706-1710.

Table 1. Refractive index, density, viscosity and dielectric constant of allyl chloride + n-Butanol mixture at $298 \mathrm{~K}$

\begin{tabular}{|c|c|c|c|c|}
\hline $\begin{array}{c}\text { Mole fraction of } \\
\text { AC }\end{array}$ & Refractive index & $\begin{array}{c}\text { Density of AC } \\
\text { n-Butanol }\end{array}$ & Viscosity & $\begin{array}{c}\text { Dielectric } \\
\text { constant }\end{array}$ \\
\hline 0 & 1.397 & 0.8055 & 2.578 & 15.40 \\
\hline 0.111 & 1.398 & 0.8155 & 2.350 & 14.58 \\
\hline 0.220 & 1.400 & 0.8255 & 2.122 & 13.77 \\
\hline 0.326 & 1.401 & 0.8365 & 1.894 & 12.96 \\
\hline 0.429 & 1.403 & 0.8485 & 1.666 & 12.13 \\
\hline 0.530 & 1.403 & 0.8606 & 1.439 & 11.32 \\
\hline 0.629 & 1.404 & 0.8732 & 1.210 & 10.49 \\
\hline 0.725 & 1.405 & 0.8851 & 0.984 & 9.68 \\
\hline 0.819 & 1.407 & 0.9002 & 0.756 & 8.85 \\
\hline 0.910 & 1.409 & 0.9119 & 0.528 & 8.06 \\
\hline 1 & 1.412 & 0.9390 & 0.301 & 7.27 \\
\hline
\end{tabular}


Table 2. $\mathrm{B}_{\mathrm{j}}$ coefficients and standard error for excess density, excess viscosity, excess refractive index, and excess molar volume

\begin{tabular}{|c|c|c|c|c|c|}
\hline \multirow{2}{*}{$\begin{array}{c}\text { Excess property } \\
\downarrow\end{array}$} & \multicolumn{4}{|c|}{$\mathrm{B}_{\mathrm{j}}$ coefficients } & \multirow{2}{*}{$\begin{array}{c}\text { Standard } \\
\text { Error }\end{array}$} \\
\cline { 2 - 5 } & $\mathrm{B}_{0}$ & $\mathrm{~B}_{1}$ & $\mathrm{~B}_{2}$ & $\mathrm{~B}_{3}$ & \\
\hline Excess density & $-3.633 \mathrm{E}-02$ & -0.0331 & $1.349 \mathrm{E}-02$ & 0.044403455 & $1.5223 \mathrm{E}-03$ \\
\hline Excess viscosity & $1.921 \mathrm{E}+00$ & $6.824 \mathrm{E}-01$ & $-3.464 \mathrm{E}-01$ & $-2.140 \mathrm{E}+00$ & $4.053 \mathrm{E}-02$ \\
\hline Excess refractive index & $-2.031 \mathrm{E}-02$ & $-8.026 \mathrm{E}-03$ & $7.014 \mathrm{E}-03$ & $-6.525 \mathrm{E}-03$ & $3.524 \mathrm{E}-04$ \\
\hline Excess molar volume & $2.095 \mathrm{E}+00$ & $3.724 \mathrm{E}+00$ & $-1.495 \mathrm{E}+00$ & $-5.355 \mathrm{E}+00$ & $1.458 \mathrm{E}-01$ \\
\hline
\end{tabular}

Table 3. Standard errors and $95 \%$ confidence intervals of the estimated $B_{j}$ coefficients for excess density, excess viscosity, excess refractive index and excess molar volume

\begin{tabular}{|c|c|c|c|c|c|}
\hline \multirow{2}{*}{$\begin{array}{c}\text { Excess property } \\
\downarrow\end{array}$} & & \multicolumn{4}{|c|}{$\mathrm{B}_{\mathrm{j}}$ coefficients } \\
\hline & & $\mathrm{B}_{0}$ & $\mathrm{~B}_{1}$ & $\mathrm{~B}_{2}$ & $\mathrm{~B}_{3}$ \\
\hline \multirow[t]{2}{*}{ Excess Density } & $\begin{array}{l}\text { standard error of } \\
\text { parameter }\end{array}$ & 0.0029 & 0.0115 & 0.0135 & 0.0299 \\
\hline & $95 \%$ confidence interval & 0.0069 & 0.0271 & 0.0318 & 0.0707 \\
\hline \multirow[t]{2}{*}{ Excess Viscosity } & $\begin{array}{l}\text { standard error of } \\
\text { parameter }\end{array}$ & 0.0004 & 0.0017 & 0.0020 & 0.0045 \\
\hline & $95 \%$ confidence interval & 0.0010 & 0.0041 & 0.0048 & 0.0107 \\
\hline \multirow[t]{2}{*}{$\begin{array}{c}\text { Excess } \\
\text { Refractive Index }\end{array}$} & $\begin{array}{l}\text { standard error of } \\
\text { parameter }\end{array}$ & 0.0007 & 0.0026 & 0.0031 & 0.0069 \\
\hline & $95 \%$ confidence interval & 0.0016 & 0.0062 & 0.0073 & 0.0163 \\
\hline \multirow{2}{*}{$\begin{array}{c}\text { Excess Molar } \\
\text { Volume }\end{array}$} & $\begin{array}{l}\text { standard error of } \\
\text { parameter }\end{array}$ & 0.2598 & 1.0201 & 1.1975 & 2.6600 \\
\hline & $95 \%$ confidence interval & 0.6143 & 2.4121 & 2.8315 & 6.2898 \\
\hline \multirow[t]{2}{*}{$\begin{array}{c}\text { Excess } \\
\text { permittivity }\end{array}$} & $\begin{array}{l}\text { standard error of } \\
\text { parameter }\end{array}$ & 0.0117 & 0.0460 & 0.0540 & 0.1199 \\
\hline & $95 \%$ confidence interval & 0.0277 & 0.1087 & 0.1276 & 0.2835 \\
\hline \multirow[t]{2}{*}{$\begin{array}{l}\text { Excess molar } \\
\text { polarization }\end{array}$} & $\begin{array}{l}\text { standard error of } \\
\text { parameter }\end{array}$ & 0.1946 & 0.7641 & 0.8969 & 1.9924 \\
\hline & $95 \%$ confidence interval & 0.4601 & 1.8068 & 2.1209 & 4.7113 \\
\hline
\end{tabular}


Table 4. Comparison of estimated values refractive index, density, viscosity and dielectric constants for pure liquids(i.e. allyl chloride and n-Butanol) at $298 \mathrm{~K}$ with the literature values

\begin{tabular}{|c|c|c|c|c|c|c|c|c|c|}
\hline Property $\downarrow$ & Liquid $\rightarrow$ & \multicolumn{4}{|c|}{ n-Butanol } & \multicolumn{4}{|c|}{ Allyl chloride } \\
\hline \multirow{3}{*}{$\begin{array}{l}\text { Refractive } \\
\text { index }\end{array}$} & This work & \multicolumn{4}{|c|}{1.397} & \multicolumn{4}{|c|}{1.412} \\
\hline & $\begin{array}{c}\text { Literature } \\
\text { value } \\
\text { (temperature) }\end{array}$ & $\begin{array}{c}1.3993 \\
(20)\end{array}$ & $\begin{array}{c}1.39741 \\
(25)\end{array}$ & $\begin{array}{c}1.39716 \\
(25)\end{array}$ & $\begin{array}{c}1.39719 \\
(25)\end{array}$ & $1.4157(20)$ & $\begin{array}{r}1.413 \\
(\quad)\end{array}$ & $\begin{array}{c}1.4157 \\
(20)\end{array}$ & $\begin{array}{l}1.414 \\
(20)\end{array}$ \\
\hline & Ref. No. & [28] & {$[35]$} & [39] & [40] & [28] & {$[18]$} & [17] & [19] \\
\hline \multirow{3}{*}{ Density } & This work & \multicolumn{4}{|c|}{0.80554} & \multicolumn{4}{|c|}{0.939} \\
\hline & $\begin{array}{c}\text { Literature } \\
\text { value } \\
\text { (temperature) }\end{array}$ & $\begin{array}{c}0.8098 \\
(20)\end{array}$ & $\begin{array}{c}0.80556 \\
(25)\end{array}$ & $\begin{array}{c}0.80567 \\
(25)\end{array}$ & $\begin{array}{l}0.80554 \\
(25)\end{array}$ & 0.81 & $\begin{array}{l}0.9376 \\
(20)\end{array}$ & $\begin{array}{c}0.9392 \\
(20)\end{array}$ & $\begin{array}{l}0.939 \\
(25)\end{array}$ \\
\hline & Ref. No. & [28] & [29] & {$[30]$} & [31] & {$[36]$} & [28] & {$[43]$} & [45] \\
\hline \multirow{3}{*}{ Viscosity } & This work & \multicolumn{4}{|c|}{2.578} & \multicolumn{4}{|c|}{0.301} \\
\hline & $\begin{array}{l}\text { Literature } \\
\text { value } \\
\text { (temperature) }\end{array}$ & $\begin{array}{c}2.948 \\
(20)\end{array}$ & $\begin{array}{c}2.578 \\
(25)\end{array}$ & $\begin{array}{l}2.2601 \\
(30)\end{array}$ & $\begin{array}{l}2.2601 \\
(30)\end{array}$ & $0.347(15)$ & $\begin{array}{c}0.354 \\
(20)\end{array}$ & $\begin{array}{l}0.32 \\
(22)\end{array}$ & $\begin{array}{l}0.34 \\
(20)\end{array}$ \\
\hline & Ref. No. & [28] & [32] & [33] & [34] & [28] & {$[46]$} & {$[47]$} & [48] \\
\hline \multirow{3}{*}{$\begin{array}{c}\text { Dielectric } \\
\text { constant }\end{array}$} & This work & \multicolumn{4}{|c|}{15.4} & \multicolumn{4}{|c|}{7.27} \\
\hline & $\begin{array}{c}\text { Literature } \\
\text { value } \\
\text { (temperature) }\end{array}$ & $\begin{array}{l}17.8 \\
(20)\end{array}$ & $\begin{array}{l}17.5 \\
(20)\end{array}$ & $\begin{array}{c}17.15 \\
(25)\end{array}$ & $\begin{array}{l}17.5 \\
(25)\end{array}$ & $8.2(20)$ & $\begin{array}{l}8.2 \\
(20)\end{array}$ & $\begin{array}{l}8.2 \\
(\quad)\end{array}$ & \\
\hline & Ref. No. & [28] & [35] & [37] & {$[38]$} & {$[44]$} & {$[41]$} & {$[42]$} & \\
\hline
\end{tabular}

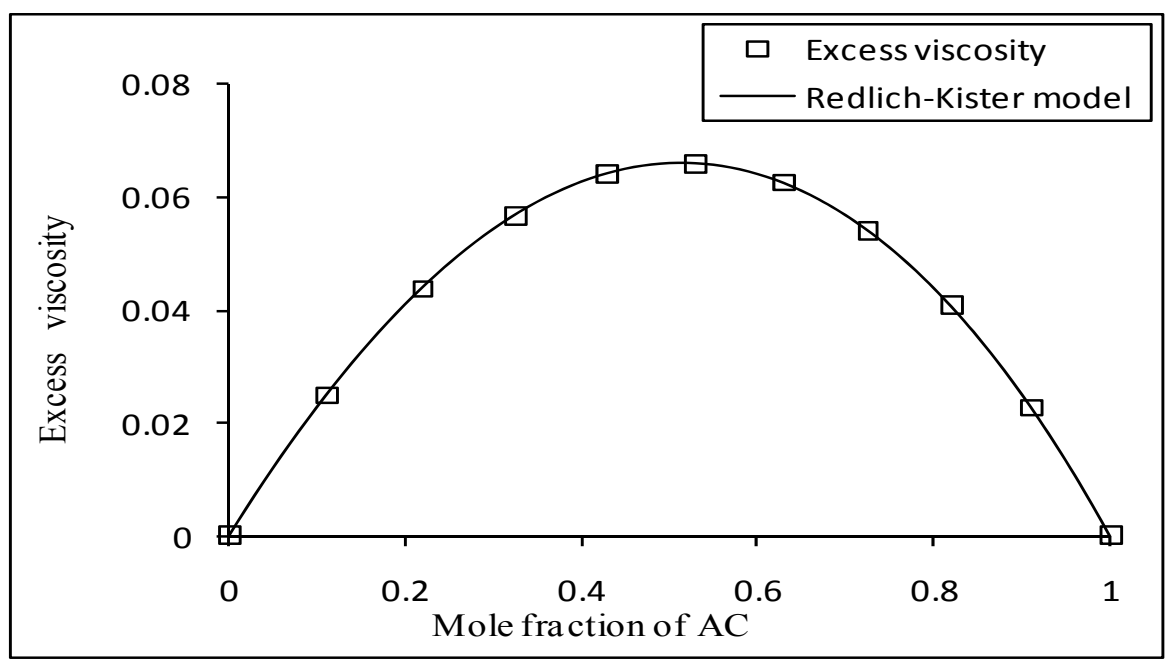

Figure 1. Variation of excess viscosity of AC + n-Butanol at 298 


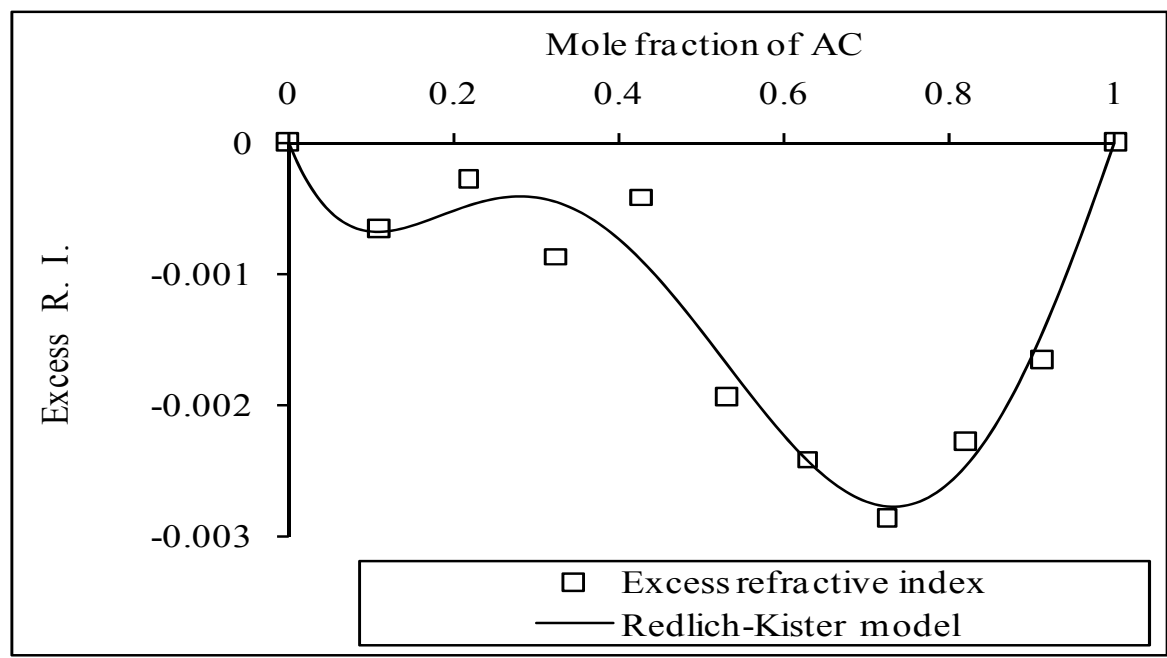

Figure 2. Variation of excess refractive index of AC $+n$-Butanol at $298 \mathrm{~K}$

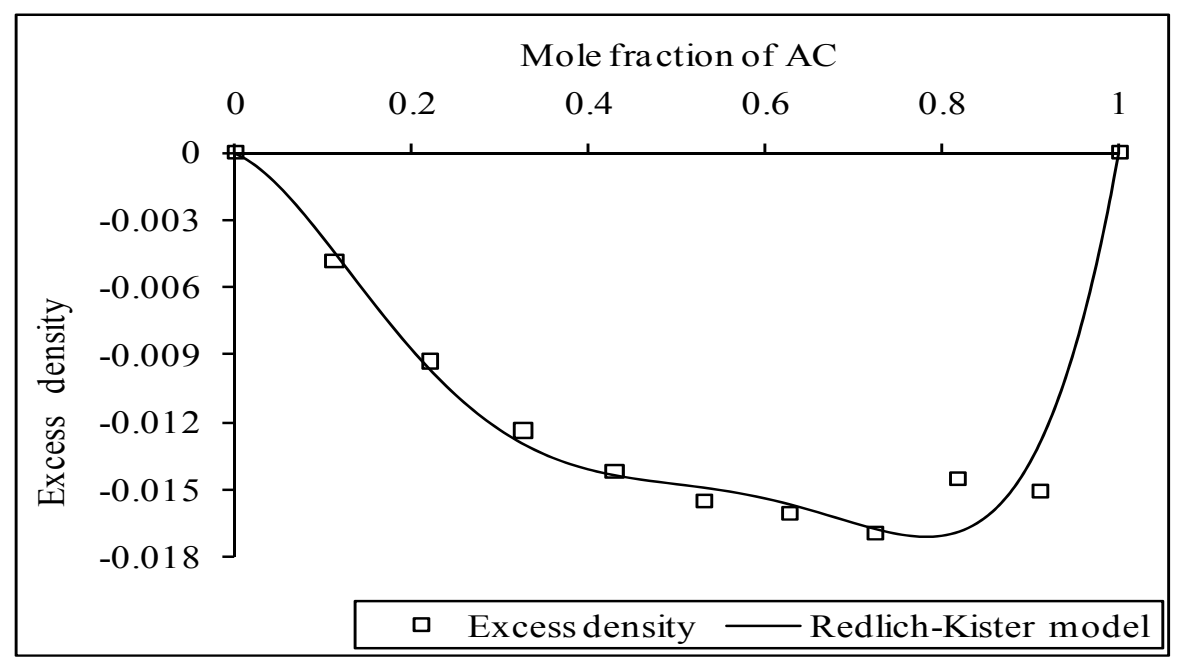

Figure 3. Variation of excess density of AC + n-Butanol at $298 \mathrm{~K}$

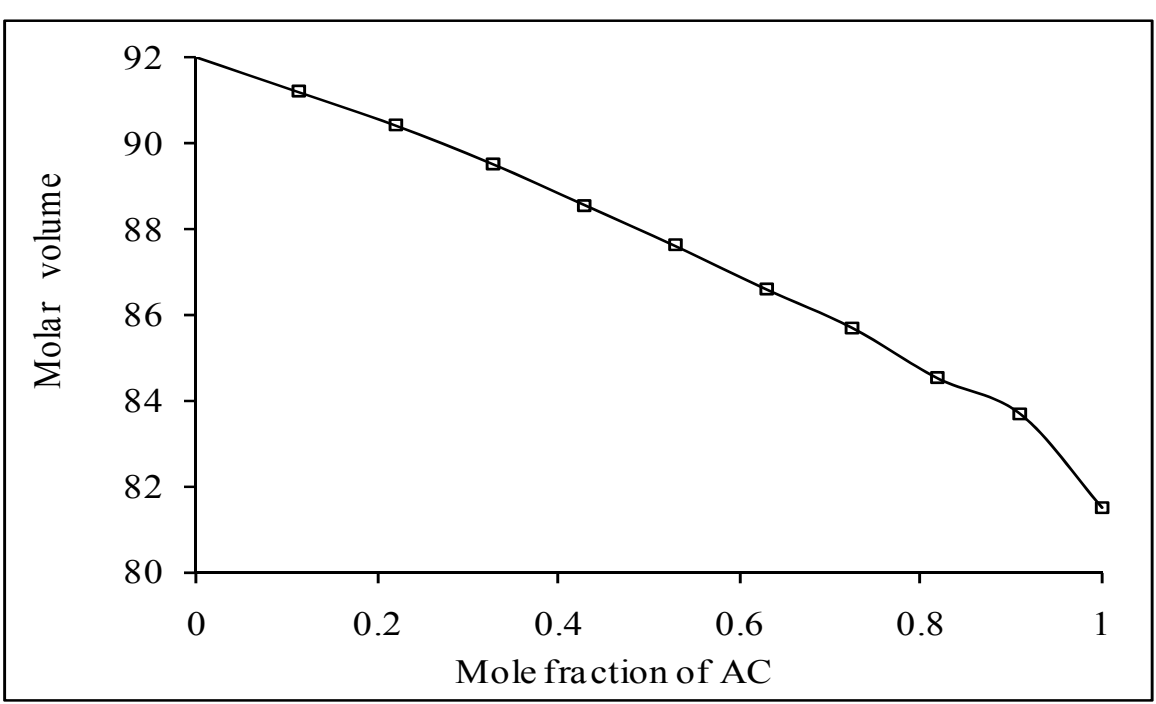

Figure 4. Variation of molar volume of AC+ n-Butanol at $298 \mathrm{~K}$ 


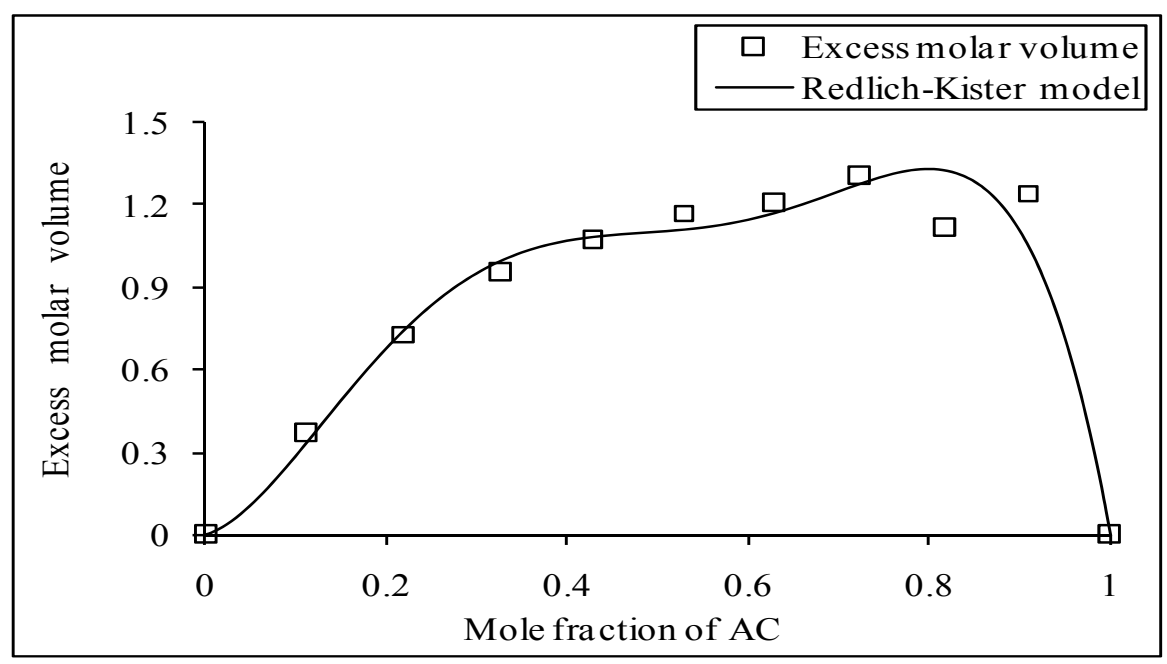

Figure 5. Variation of excess molar volume of $\mathrm{AC}+\mathrm{n}$-Butanol at $298 \mathrm{~K}$

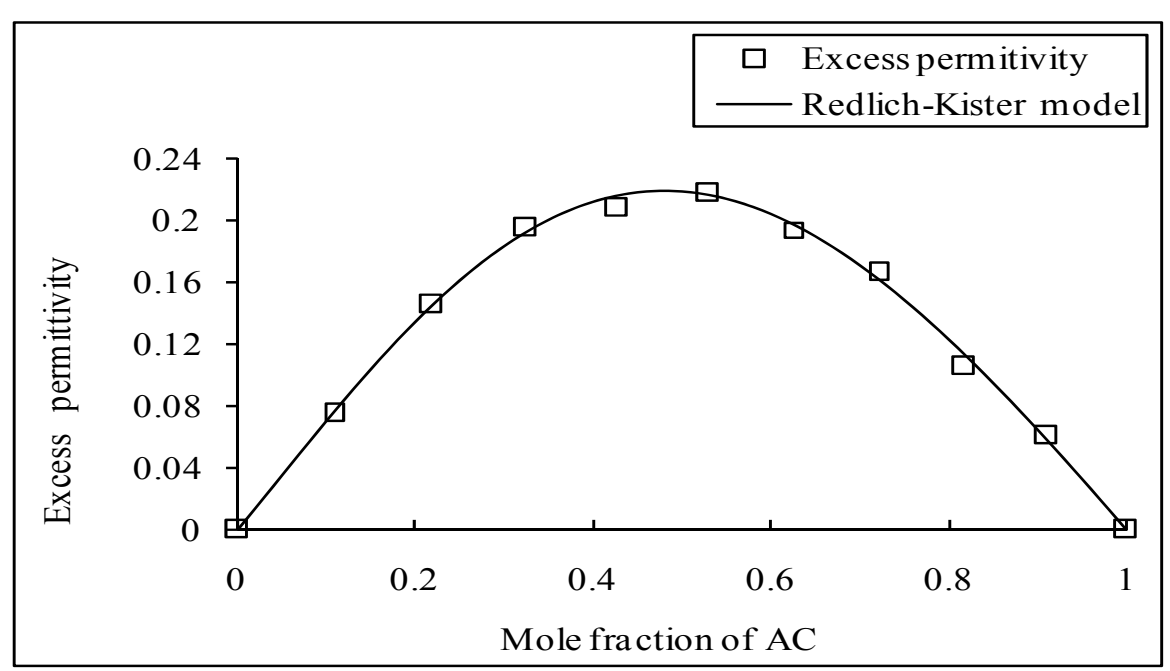

Figure 6. Variation of excess permitivityof AC + n-Butanol at $298 \mathrm{~K}$

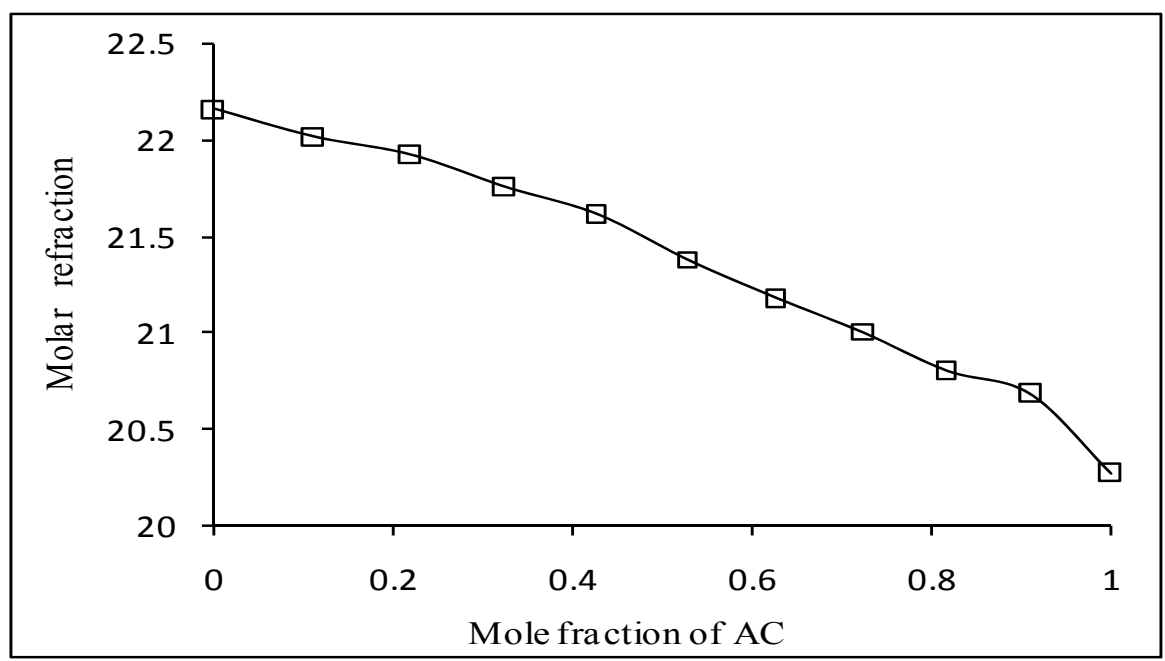

Figure 7. Variation of molar refraction of AC $+n-B u t a n o l$ at $298 \mathrm{~K}$ 


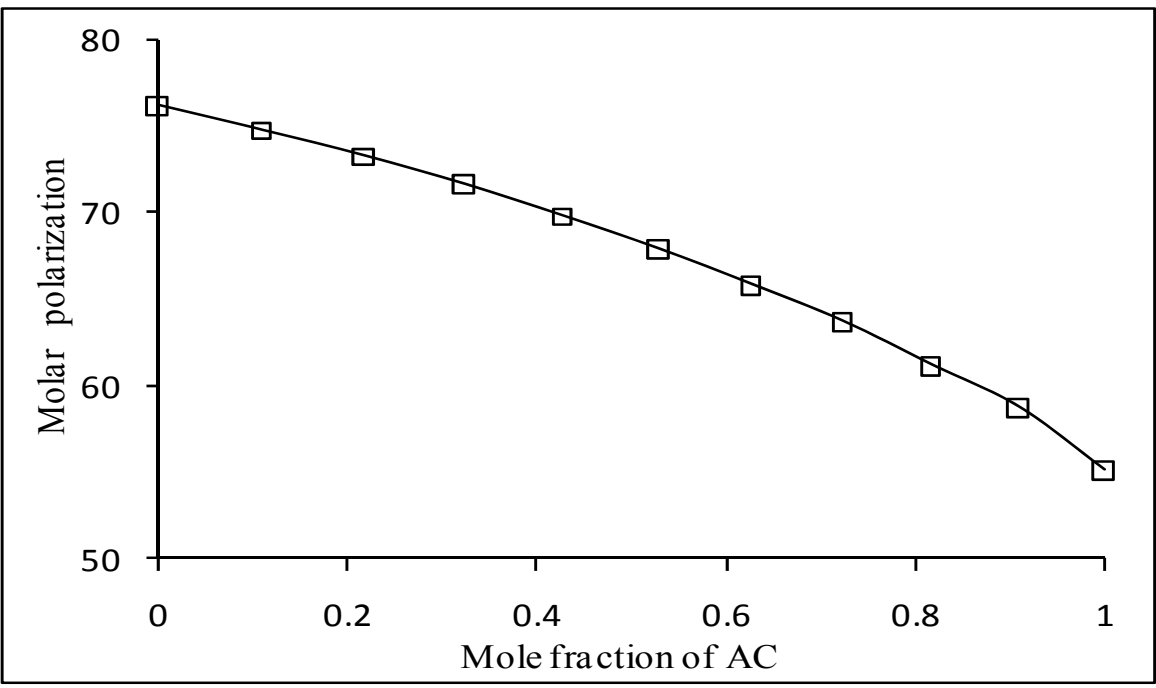

Figure 8. Variation of molar polarization of AC + n-Butanol at $298 \mathrm{~K}$

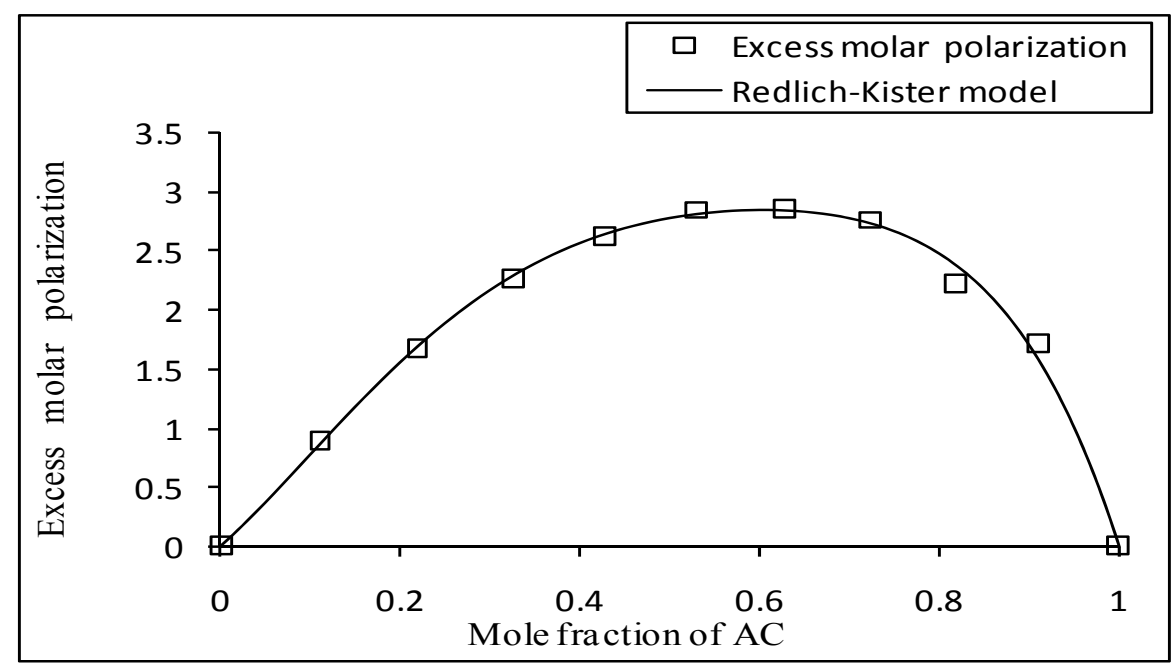

Figure 9. Variation of excess molar polarization of AC $+n-B u t a n o l$ at $298 \mathrm{~K}$

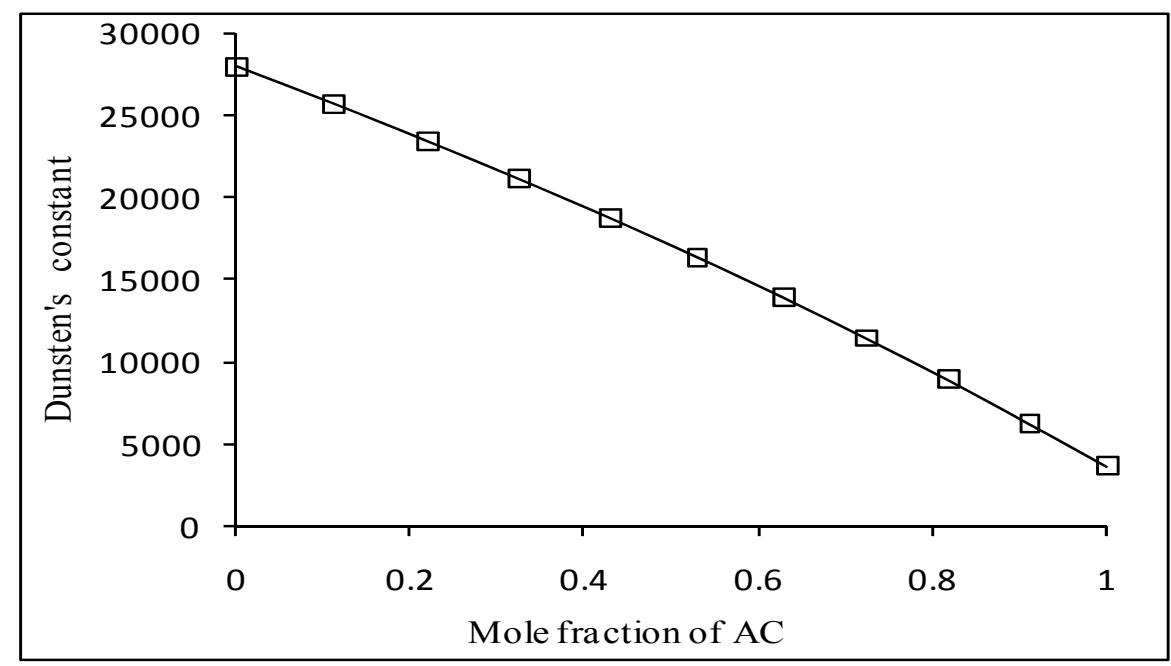

Figure 10. Variation of Dunstan's constant of AC + n-Butanol at $298 \mathrm{~K}$ 